\title{
Effect of Betaine Diet on Growth Performance, Carcass Quality and Fat Deposition in Finishing Ningxiang Pigs
}

\author{
Yaodong Wang $\mathbb{D}^{\mathrm{D}}$, Jiayi Chen $(\mathbb{D}$, Yingli Ji, Xue Lin and Yurong Zhao *(D) \\ College of Animal Science \& Technology, Hunan Agricultural University, Changsha 410125, China; \\ sxllwyd@gmail.com (Y.W.); jiayi@stu.hunau.edu.cn (J.C.); jiyingli168@163.com (Y.J.); risca@tanke.com.cn (X.L.) \\ * Correspondence: zyr@hunau.edu.cn
}

check for updates

Citation: Wang, Y.; Chen, J.; Ji, Y.; Lin, X.; Zhao, Y. Effect of Betaine Diet on Growth Performance, Carcass Quality and Fat Deposition in Finishing Ningxiang Pigs. Animals 2021, 11, 3408. https://doi.org/ 10.3390/ani11123408

Academic Editors: José

Francisco Pérez and

Manuel Fondevila

Received: 7 October 2021

Accepted: 27 November 2021

Published: 29 November 2021

Publisher's Note: MDPI stays neutral with regard to jurisdictional claims in published maps and institutional affiliations.

Copyright: (C) 2021 by the authors. Licensee MDPI, Basel, Switzerland. This article is an open access article distributed under the terms and conditions of the Creative Commons Attribution (CC BY) license (https:/ / creativecommons.org/licenses/by/ $4.0 /)$.
Simple Summary: Excessive fat deposit is one of the major problems in finishing Ningxiang pigs, and adversely affects the breeding. The study aimed to investigate the effects of diet with betaine supplementation (basal diet $+0.2 \%$ betaine) on the growth performance, slaughter performance, meat quality and the genes expression related to fat deposition in finishing Ningxiang pigs. The results indicated that diet with betaine supplementation decreased back fat thickness and fat percentage, and increased the lean meat percentage as well. In addition, it reduced the fat deposition by regulating the genes expression. These findings provided a reference for breeding Ningxiang pigs.

Abstract: The present study was conducted to investigate the effects of diet with betaine supplementation on the growth performance, carcass quality and fat deposition in finishing Ningxiang pigs. A total of 24 Ningxiang pigs ( $43.6 \pm 5.34 \mathrm{~kg}$ of average body weight) was randomly divided into two groups, with 6 replicates per treatment and 2 pigs per replicate. The treatments included a control group (basal diet) and a test group (basal diet $+0.2 \%$ betaine). The whole trial lasted 81 days. At the end of the experiment, one pig (close to the average body weight of all experimental pigs) per replicate was slaughtered to determine the carcass traits, meat quality and the mRNA expression levels of genes relate to fat deposition (one pig per replicate was randomly selected and fasted for $12 \mathrm{~h}, n=6$ ). Results indicated that growth performance was not changed with betaine supplementation. However, dietary with betaine supplementation decreased back fat thickness and fat percentage, and increased the lean meat percentage as well $(p<0.05)$. In addition, diet with betaine supplementation reduced drip loss, water loss, cooking loss, shear force and $\mathrm{b} \times 24 \mathrm{~h}$ value of meat $(p<0.05)$. There was no difference in total moisture, ether extract and crude protein of longissimus thoracis between the control and test group. Dietary with betaine supplementation decreased ether extract and total cholesterol $(p<0.05)$ in liver. Dietary with betaine supplementation upregulated the mRNA expression levels of adipose triglyceride lipase (ATGL) and sirtuin 1 (Sirt1), while downregulated the mRNA expression levels of fatty acid synthase (FAS) and acetyl CoA carboxylase (ACC) in subcutaneous fat of back $(p<0.05)$. Besides, dietary with betaine supplementation upregulated the fatty acid binding protein 4 (FABP4) mRNA expression of longissimus thoracis in finishing Ningxiang pigs $(p<0.05)$. These results showed that diet supplemented with betaine could improve the slaughtering performance and meat quality, and regulate the genes expression to affect the fat deposition in finishing Ningxiang pigs.

Keywords: betaine; carcass quality; fat deposition; Ningxiang pig; meat quality

\section{Introduction}

Fat is an important tissue for storing energy, and is closely related to livestock and poultry production and meat quality [1]. Excessive fat deposition will decrease the lean meat percentage, the meat quality and the ratio of feed conversion, and even cause serious health problems such as fatty liver [2]. 
Ningxiang pig, as a local pig breed of China, occupies an important position in Chinese pork consumption with its delicious taste-as a fat-type pig, it has strong ability to deposit fat [3]. Lei et al. [4] reports that Ningxiang pigs exhibit higher back fat thickness than Large White pigs (4.54\% vs. $2.61 \%)$. He et al. [5] conclude that Ningxiang pigs have higher fat mass ( $42.3 \%$ vs. $21.9 \%)$ and lower muscle mass $(35.4 \%$ vs. $58.9 \%)$ than Duroc $\times$ Landrace $\times$ Large Yorkshire pigs. Therefore, it is necessary to find a way to decrease the fat deposition in Ningxiang pigs for high feed conversion efficiency with lower cost. As an intermediate product of metabolism process, betaine generally exists in animals and plants. With the further maturity of betaine chemical synthesis method and the continuous reduction of production cost, betaine has been widely used in livestock and poultry production [6]. Fernández et al. [7] found that betaine supplementation increased lean deposition in growing Iberian gilts. Therefore, it was hypothesized that betaine supplementation may reduce fat deposition and improve lean meat percentage in finishing Ningxiang pigs. The study was conducted to explore the effect of betaine supplementation on growth performance, carcass quality and fat metabolism in finishing Ningxiang pigs, which provide theoretical basis for the development and utilization of betaine in Ningxiang pigs.

\section{Materials and Methods}

\subsection{Diet and Animal Management}

The purity of betaine (Skystone Feed Co., Ltd., Yixing, China) was 96\%. This experiment was conducted in Bangshifu pig farm (Changsha, China) and the study was approved by the Biomedical Research Ethics Committee of Hunan Agricultural University (the authorization number from ethical committee is 2021, No. 91). A total of 24 Ningxiang pigs ( $43.6 \pm 5.34 \mathrm{~kg}$ of average body weight) was randomly divided into two groups, with 6 replicates per treatment and 2 pigs per replicate (1:1 ratio of gilt and boar). The whole trial lasted 81 days. Pigs were fed three times per day with free access to water. The treatments included a control group (basal diet) and a test group (basal diet $+0.2 \%$ betaine). Basis diets were designed with the recommendations of Chinese National Feeding Standard Type 2 for fatty growing pigs (2020), as shown in Table 1.

Table 1. Composition and nutrient levels of basal diets (air-dry basis) ${ }^{1}$.

\begin{tabular}{ccc}
\hline Ingredients (\%) & CON & BET \\
\hline Corn & 54.90 & 54.90 \\
Wheat bran & 21.30 & 21.30 \\
Soybean meal & 8.20 & 8.20 \\
Rice bran & 6.40 & 6.40 \\
Corn oil & 3.20 & 3.20 \\
Zeolite & 1.90 & 1.69 \\
Straw & 1.70 & 1.70 \\
Limestone & 1.01 & 1.01 \\
Premix ${ }^{2}$ & 1.00 & 1.00 \\
CaHPO 4 & 0.27 & 0.27 \\
Lysine, $98 \%$ & 0.11 & 0.11 \\
Threonine $98 \%$ & 0.01 & 0.01 \\
Betaine $96 \%$ & 0.00 & 0.21 \\
Total & 100.00 & 100.00 \\
Nutrient levels 3 & & \\
Digestible energy, MJ/kg & 13.03 & 13.03 \\
Crude protein, \% & 12.01 & 12.01 \\
Crude fat, \% & 5.28 & 5.28 \\
Crude Fiber, \% & 4.07 & 4.07 \\
Lysine, \% & 0.60 & 0.60 \\
Total phosphorus \% & 0.53 & 0.53 \\
\hline
\end{tabular}


Table 1. Cont.

\begin{tabular}{ccc}
\hline Ingredients (\%) & CON & BET \\
\hline Calcium, \% & 0.50 & 0.50 \\
Threonine, \% & 0.44 & 0.44 \\
Methionine, \% & 0.20 & 0.20 \\
Available phosphorus, \% & 0.16 & 0.16 \\
Tryptophan, \% & 0.13 & 0.13 \\
\hline
\end{tabular}

${ }^{1}$ Basal diet formulated according to the Chinese National Feeding Standard for Swine. ${ }^{2}$ The premix supplied, per kg of diet: VA $1300 \mathrm{IU}, \mathrm{VD} 3150 \mathrm{IU}, \mathrm{VE} 11 \mathrm{IU}, \mathrm{VK} 30.5 \mathrm{mg}$, VB1 $1.2 \mathrm{mg}$, VB2 $2 \mathrm{mg}$, VB6 $1.3 \mathrm{mg}, \mathrm{VB} 125 \mu \mathrm{g}$ folic acid $0.3 \mathrm{mg}$, pantothenic acid $7 \mathrm{mg}$, Cu $5 \mathrm{mg}$, I $3 \mathrm{mg}$, Se $0.15 \mathrm{mg}, \mathrm{Zn} 80 \mathrm{mg}$, Fe $80 \mathrm{mg}$, Mn $60 \mathrm{mg}$, NaCl $3600 \mathrm{mg} .{ }^{3}$ The contents of digestible energy, crude protein, crude fiber, calcium and total phosphorus were analyzed, Nutrient levels were calculated according to the tables of feed composition and nutritive values in China (30th edition in 2019) [8]. CON, control diet group. BET, betaine diet group.

\subsection{Sampling and Measurements}

Pigs were weighed at the beginning and the end of the experiment, individually. The feed intake was recorded weekly and calculated for each pen. The average daily gain (ADG), average daily feed intake (ADFI), and feed conversion ratio (FCR) were then calculated using this information for each phase.

At the end of the experiment, one pig (close to the average body weight of all experimental pigs) per replicate was slaughtered to determine the carcass traits and meat quality (one pig per replicate was randomly selected and fasted for $12 \mathrm{~h}, n=6$ ). Samples of longissimus thoracis (LT), subcutaneous fat of back and liver were collected from the right side of the carcass stored at liquid nitrogen, and then stored at $-80^{\circ} \mathrm{C}$ for further analysis.

The carcass traits included: slaughter rate $(\%)=($ slaughter weight $/$ live weight $) \times 100$; carcass weight: the body weight after slaughter with removed head, hoof, tail and viscera and retained the oil and kidney; fat rate $(\%)=($ fat weight/live weight $) \times 100$; lean rate $(\%)=($ lean weight $/$ carcass weight $) \times 100$; back fat thickness: take the average back fat thickness of shoulder, thoracolumbar junction and lumbar sacral junction of the left side of carcass.

Pork quality was determined according to the method of Honikel [9]. Meat color (lightness, redness and yellowness) was determined after slaughter (45 min and $24 \mathrm{~h}$ ) by using reflectance spectrophotometer (CR-410, Konica Minolta Sensing Inc., Osaka, Japan). Cooking loss was determined by using weighted meat sample placed in a pot cooked to a core temperature of $70^{\circ} \mathrm{C}$, and then taken out and cooled for $30 \mathrm{~min}$ before weight. The ratio of the reduced weight of the meat sample to the initial weight was the cooking loss. The cooking loss, shearing force, drip loss and water loss were measured according to the method described by Chen [10].

Total moisture, ether extract (EE) of liver and longissimus thoracis samples were analyzed referring to the Association of Analytical Chemists methods (AOAC 2000) [11]. Triglyceride (TG) and total cholesterol (TC) was measured using TG and TC kit (Nanjing Jiancheng Bioengineering Institute) according to the manufacturer's protocol.

\subsection{Quantitative Real-Time PCR Analysis}

Total RNA was isolated from longissimus thoracis and subcutaneous fat of back with Trizol reagent (Beijing Solarbio Science \& Technology Co., Ltd., Beijing, China) according to the method described by Chen [10]. The purity and integrity of RNA were detected by Nanodrop (Thermo Scientific, Waltham, Massachusetts, USA) and electrophoresis in $1 \%$ agarose gel, respectively. Reverse transcription of the total RNA with RT Reagents (Hunan Accurate Biotechnology Co., Ltd., Changsha, China). The qPCR cycling program were as follows: an initial denaturation at $95^{\circ} \mathrm{C}$ for $30 \mathrm{~s}$ and 40 cycles of denaturation at $95^{\circ} \mathrm{C}$ for $5 \mathrm{~s}$ and annealing and extension at $60^{\circ} \mathrm{C}$ for $30 \mathrm{~s}$. The relative expression levels of mRNA were calculated by using the $2^{-(\Delta \Delta C T)}$ method [12]. The considered genes include acetyl-CoA carboxylase (ACC), fatty acid synthetase (FAS), adipose triglyceride lipase (ATGL), fatty acid-binding protein4 (FABP4) and sirtuin1 (Sirt1). $\beta$-actin was chosen 
as the housekeeping gene. The primers were designed via Primer 5.0 software; sequences of primers are shown in Table 2.

Table 2. Primers used for quantitative real-time PCR.

\begin{tabular}{|c|c|c|c|}
\hline Gene & Accession No. & Primer Sequence $\left(5^{\prime}-3^{\prime}\right)$ & Product Size (bp) \\
\hline$\beta$-ACTIN & NM_001170517.2 & $\begin{array}{l}\text { F:CCTGCGGCATCCACGAAAC } \\
\text { R:TGTCGGCGATGCCTGGGTA }\end{array}$ & 123 \\
\hline ACC & NM-001114269 & $\begin{array}{l}\text { F:GGCCATCAAGGACTTCAACC } \\
\text { R:ACGATGTAAGCGCCGAACTT }\end{array}$ & 120 \\
\hline FAS & NM_001099930.1 & $\begin{array}{l}\text { F:ACACCTTCGTGCTGGCCTAC } \\
\text { R:ATGTCGGTGAACTGCTGCAC }\end{array}$ & 112 \\
\hline FABP4 & NM_001002817.1 & $\begin{array}{l}\text { F:GGGCCAGGAATTTGATGAAG } \\
\text { R:CTTTCCATCCCACTTCTGCAC }\end{array}$ & 103 \\
\hline ATGL & NM_001098605.1 & $\begin{array}{l}\text { F:CATCCGTGGCTGCCTGGTGAA } \\
\text { R:CCTGGCGGCGAAGTGGGTTAT }\end{array}$ & 127 \\
\hline Sirt1 & NM_001145750.2 & $\begin{array}{l}\text { F:GCAGGAATCCAGAGG } \\
\text { R:GGTCTTACTTTCAGGGA }\end{array}$ & 281 \\
\hline
\end{tabular}

ACC, acetyl-CoA carboxylase. FAS, fatty acid synthetase. ATGL, adipose triglyceride lipase. FABP4, fatty acid-binding protein4. Sirt1, sirtuin1.

\subsection{Statistical Analysis}

All data were analyzed to evaluate whether data were normally distributed by using IBM SPSS Statistics 22.0. The repeated measurements were tested by using ANOVA. Differences among means were tested by using the method of the T-test. Results were expressed as the mean \pm standard error of means (SEM). $p \leq 0.05$ was considered to be statistically significant.

\section{Results}

\subsection{Growth Performance}

There was no difference of ADG, ADFI and FCR between the control and test group (Table 3).

Table 3. Effect of betaine on growth performance of finishing Ningxiang pigs.

\begin{tabular}{ccccc}
\hline Items & CON & BET & SEM & $p$ Value \\
\hline Initial body weight $(\mathrm{kg})$ & 44.81 & 42.38 & 1.334 & 0.379 \\
Final body weight $(\mathrm{kg})$ & 72.50 & 72.44 & 1.309 & 0.982 \\
Average daily gain (ADG, g) & 0.34 & 0.37 & 0.017 & 0.430 \\
Average daily feed intake (ADFI, kg) & 1.65 & 1.74 & 0.044 & 0.287 \\
Feed conversion ratio (FCR) & 4.89 & 4.79 & 0.142 & 0.746
\end{tabular}

$\overline{\mathrm{CON}}$, control diet group. BET, betaine diet group. ADG, average daily gain. ADFI, average daily feed intake. FCR, feed conversion ratio.

\subsection{Slaughtering Performance}

Diet with betaine supplementation decreased fat percentage $(p<0.05$; Table 4$)$, back fat thickness $(p<0.05)$ and had no effect on slaughter rate.

Table 4. Effect of betaine on slaughtering performance of finishing Ningxiang pigs.

\begin{tabular}{ccccc}
\hline Items & CON & BET & SEM & $p$ Value \\
\hline Live weight $(\mathrm{kg})$ & 73.92 & 74.17 & 1.312 & 0.929 \\
Carcass weight $(\mathrm{kg})$ & 54.72 & 54.55 & 1.231 & 0.949 \\
Slaughter rate $(\%)$ & 73.95 & 73.55 & 0.682 & 0.787 \\
Fat percentage (\%) & $39.50^{\mathrm{a}}$ & $36.40^{\mathrm{b}}$ & 0.680 & 0.014 \\
Lean meat percentage (\%) & $39.53^{\mathrm{a}}$ & $42.23^{\mathrm{b}}$ & 0.685 & 0.042 \\
Back fat thickness (mm) & $39.69^{\mathrm{a}}$ & $34.92^{\mathrm{b}}$ & 1.062 & 0.016 \\
\hline
\end{tabular}

CON, control diet group. BET, betaine diet group. ${ }^{\mathrm{a}, \mathrm{b}}$ mean in the same row with different letter superscripts signal a significant difference, ${ }^{\text {a }}$ as the highest numerical value $(p \leq 0.05)$. 


\subsection{Meat Quality}

Diet with betaine supplementation decreased shearing force, drip loss and cooking loss $\left(p<0.05 ;\right.$ Table 5). It also decreased $b^{*} 24 \mathrm{~h}$ value $(p<0.05)$ with no effect on redness and lightness.

Table 5. Effect of betaine on the meat quality of finishing Ningxiang pigs.

\begin{tabular}{|c|c|c|c|c|c|}
\hline \multicolumn{2}{|c|}{ Items } & \multirow{2}{*}{$\begin{array}{l}\text { CON } \\
10.41\end{array}$} & \multirow{2}{*}{$\begin{array}{c}\text { BET } \\
10.11\end{array}$} & \multirow{2}{*}{$\begin{array}{l}\text { SEM } \\
0.538\end{array}$} & \multirow{2}{*}{$\begin{array}{c}p \text { Value } \\
0.800\end{array}$} \\
\hline & $\mathrm{a}^{*} 45 \min$ & & & & \\
\hline Redness & $a^{*} 24 h$ & 11.33 & 10.63 & 0.606 & 0.588 \\
\hline \multirow{2}{*}{ Yellowness } & $\mathrm{b}^{*} 45 \min$ & 6.09 & 4.99 & 0.389 & 0.166 \\
\hline & $b^{*} 24 h$ & $6.30^{\mathrm{a}}$ & $5.06^{\mathrm{b}}$ & 0.290 & 0.025 \\
\hline \multirow{2}{*}{ Lightness } & $\mathrm{L}_{45}^{*} \min$ & 46.27 & 42.75 & 2.119 & 0.432 \\
\hline & $\mathrm{L}^{*} 24 \mathrm{~h}$ & 47.08 & 43.92 & 1.801 & 0.407 \\
\hline \multicolumn{2}{|c|}{ Shearing force $(\mathrm{N})$} & $43.42^{\mathrm{a}}$ & $39.65^{b}$ & 0.699 & 0.001 \\
\hline \multicolumn{2}{|c|}{ Drip loss (\%) } & $1.80^{\mathrm{a}}$ & $1.16^{\mathrm{b}}$ & 0.134 & 0.009 \\
\hline \multicolumn{2}{|c|}{ Cooking loss (\%) } & $35.77^{a}$ & $32.77^{b}$ & 0.693 & 0.021 \\
\hline
\end{tabular}

CON, control diet group. BET, betaine diet group. ${ }^{\mathrm{a}, \mathrm{b}}$ mean in the same row with different letter superscripts signal a significant difference, ${ }^{a}$ as the highest numerical value $(p \leq 0.05)$.

\subsection{Longissimus Thoracis Chemical Composition and Biochemical Parameters}

There was no difference in total moisture, ether extract and crude protein of longissimus thoracis between the control and test group (Table 6).

Table 6. Effect of betaine on the longissimus thoracis chemical composition and biochemical parameters of finishing Ningxiang pigs.

\begin{tabular}{ccccc}
\hline Items & CON & BET & SEM & $p$ Value \\
\hline $\begin{array}{c}\text { Total moisture } \\
(\%)\end{array}$ & 74.78 & 75.52 & 0.592 & 0.567 \\
$\begin{array}{c}\text { Ether extract (EE, } \\
\%)\end{array}$ & 2.12 & 2.08 & 0.064 & 0.818 \\
$\begin{array}{c}\text { Crude protein } \\
(\mathrm{CP}, \%)\end{array}$ & 22.48 & 21.92 & 0.369 & 0.475 \\
\hline
\end{tabular}

$\overline{\mathrm{CON}}$, control diet group. BET, betaine diet group. EE, ether extract. $\mathrm{CP}$, crude protein.

\subsection{Liver Chemical Composition and Biochemical Parameters}

Dietary with betaine supplementation decreased ether extract and total cholesterol $(p<0.05$; Table 7$)$ in liver.

Table 7. Effect of betaine on the liver chemical composition and biochemical parameters of finishing Ningxiang pigs.

\begin{tabular}{ccccc}
\hline Items & CON & BET & SEM & $p$ Value \\
\hline Total moisture (\%) & 71.28 & 70.93 & 0.098 & 0.068 \\
Ether extract (EE, \%) & $3.80^{\mathrm{a}}$ & $2.60^{\mathrm{b}}$ & 0.224 & 0.002 \\
Triglyceride (TG, mmol/L) & $2.82^{\mathrm{a}}$ & 2.88 & 0.094 & 0.751 \\
Total cholesterol (TC, mmol/L) & $0.98^{\mathrm{a}}$ & $0.75^{\mathrm{b}}$ & 0.047 & 0.007
\end{tabular}

CON, control diet group. BET, betaine diet group. EE, ether extract. TG, triglyceride. TC, total cholesterol. $\mathrm{a}, \mathrm{b}$ mean in the same row with different letter superscripts signal a significant difference, ${ }^{\mathrm{a}}$ as the highest numerical value $(p \leq 0.05)$.

\subsection{Relative mRNA Expression Levels}

The relative mRNA expression levels of FABP4 upregulated in longissimus thoracis of the BET group $(p<0.05$; Figure 1$)$. There was no difference in the relative mRNA expression levels of FAS and ACC between two groups. 
FAS

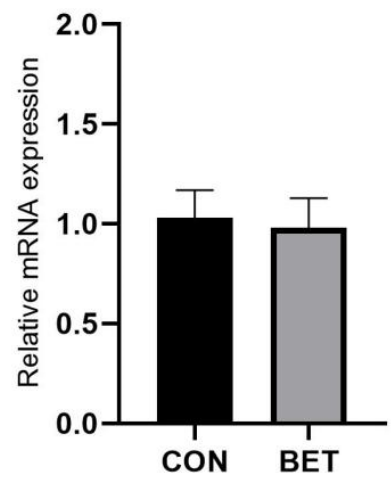

ACC

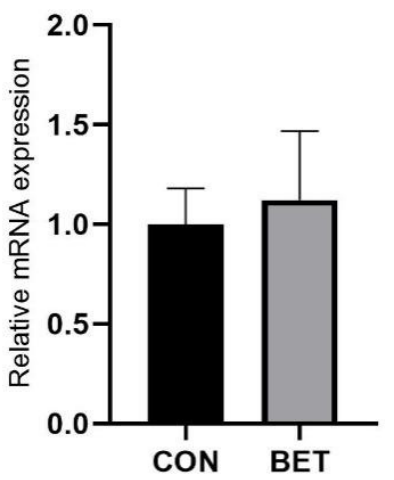

FABP4

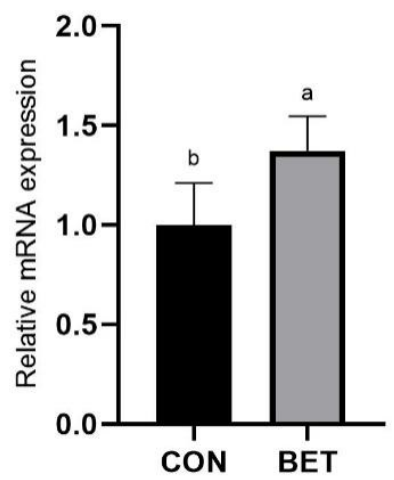

Figure 1. mRNA expression of longissimus thoracis (LT) in finishing Ningxiang pigs fed with betaine. The relative mRNA expression levels of the key genes related to fat metabolism including acetyl-CoA carboxylase (ACC), fatty acid synthetase (FAS), fatty acid-binding protein4 (FABP4) $(n=6)$. CON, control diet group. BET, betaine diet group. ${ }^{\mathrm{a}, \mathrm{b}}$ mean in the same row with different letter superscripts signal a significant difference, ${ }^{a}$ as the highest numerical value $(p \leq 0.05)$.

As shown in Figure 2, in subcutaneous back fat of the BET group, the relative mRNA expression levels of ACC and FAS downregulated significantly $(p<0.05)$ and the mRNA expression of ATGL and Sirt1 upregulated $(p<0.05)$. However, the expression of FABP4 showed no difference when compared to the control group.

ACC

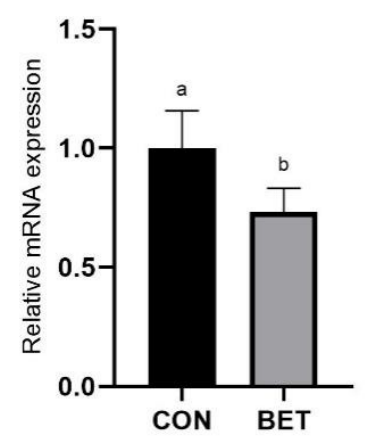

FAS

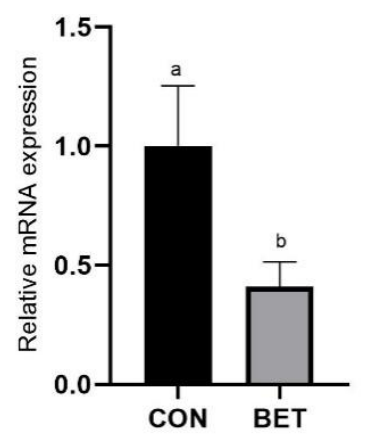

ATGL

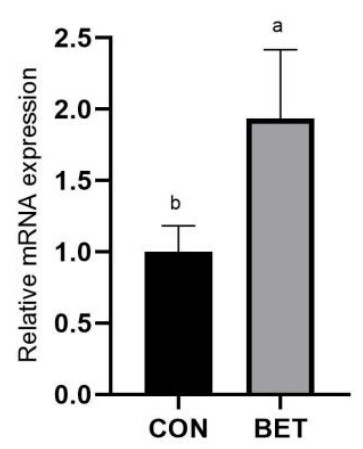

Sirt1

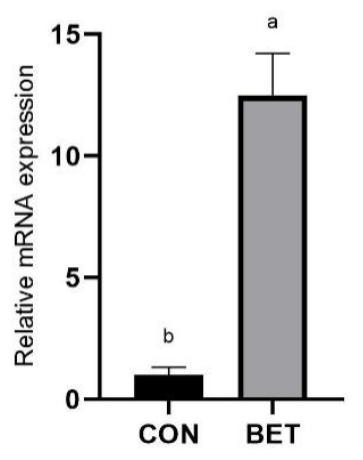

FABP4

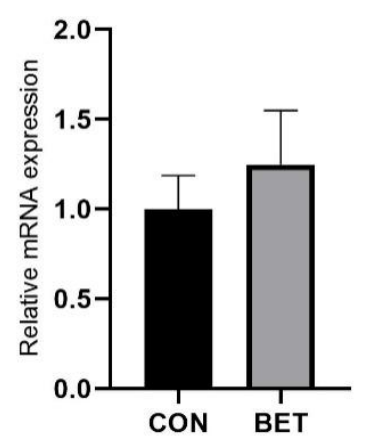

Figure 2. mRNA expression of fat metabolism related genes in subcutaneous back fat. The relative mRNA expression levels of the key genes related to fat metabolism including acetyl-CoA carboxylase (ACC), fatty acid synthetase (FAS), adipose triglyceride lipase (ATGL), fatty acid-binding protein4 (FABP4), sirtuin1 (Sirt1) $(n=6)$. CON, control diet group. BET, betaine diet group. ${ }^{\mathrm{a}, \mathrm{b}}$ mean in the same row with different letter superscripts signal a significant difference, ${ }^{\mathrm{a}}$ as the highest numerical value $(p \leq 0.05)$. 


\section{Discussion}

There were studies reporting that diet with betaine supplementation might upregulate the growth performance in pigs [13]. However, there were no differences of ADG, ADFI and FCR between the control and test group in this study, which were in line with Albuquerque et al. [14] and Sale et al. [15].

Meat quality is an important actor for livestock and poultry production and used to be evaluated by meat color, shearing force, drip loss, cooking loss and others. In general, meat color is the first consideration for people to make a purchase decision, although meat color is not the most reliable forecaster for its safety and quality [16]. Besides, the percentage of intramuscular fat (IMF) is also the important actor of meat quality. Additionally, there were researches reporting the positive effect of IMF on meat quality [17-19]. Meat color depends on the content of meat pigment, which is mainly composed of myoglobin, hemoglobin and trace-colored metabolites. Yu et al. [20] found that meat color scores were correlated to the proportion of oxymyoglobin, and negatively correlated with deoxymyoglobin and metmyoglobin content. Therefore, the meat color has a close relationship with the quality of meat. This study presented no marked change on $a^{*}$ and $L^{*}$ value of meat, which was consistent with the result of other research [21]. However, $b^{*}{ }_{24 h}$ value of the BET diet group was markedly decreased. Thus, it indicated that betaine diet has a positive effect on the meat color. Besides, the study found that diet with betaine supplementation decreased the drip loss, cooking loss and shear force of the LT muscle, while increasing the waterholding capacity and tenderness of the muscles. These were consistent with other studies that betaine can maintain the balance of water in the cell by the special structure, so that betaine diet can greatly affect water-holding capacity in meat $[22,23]$. As a result of the less exudated water distributing on the surface of the muscle fiber, the ability to reflect light was weakened, thus $b^{*}{ }_{24 h}$ value of meat with betaine diet decreased [24]. The present study indicated that the expression of FABP4 in LT muscles of the BET diet group was significantly upregulated. However, it was found that there was no difference in ether extract on longissimus thoracis between the control and test group. As a candidate gene for IMF deposition [25], FABP4 affects metabolic pathways by regulating transport of fatty acids and other ligands $[26,27]$. The present results indicated that diets supplemented with betaine upregulated the expression of FABP4. However, it had no negative effect on ether extract of longissimus thoracis. In summary, dietary with betaine supplementation could affect the meat quality via decreasing $\mathrm{b}^{*}{ }_{24 \mathrm{~h}}$ value of meat, increasing the water-holding capacity and tenderness of the muscles. Additionally, diet with betaine supplementation has no negative effect on ether extract of muscle.

Present results indicated that diet with betaine supplementation decreased the levels of EE and TC in liver, which was consistent with previous studies [28]. Fat is an important part of the body, playing a key role in storing and supplying energy, maintaining body temperature, fixing internal organs and promoting the absorption of fat-soluble vitamins. However, excessive fat deposition makes negative influence on growth and even causes illness [29]. As the main metabolic organ of the body, the liver is an important center of fat synthesis and decomposition. Betaine is involved in the fat oxidation in the liver. In addition, betaine can supply methyl for the body to produce lecithin and carnitine, which can promote the metabolization of fat in liver [30,31]. Thus, dietary with betaine supplementation decreased the level of TC in the liver.

Fat metabolism includes the deposition, synthesis, decomposition and transport. Fat deposition is actually the proliferation and growth of adipocytes. The key to control the proliferation and growth of adipocytes is to regulate the synthesis and decomposition of fat. ACC is the rate-limiting enzyme for fatty acid de novo synthesis [32,33]. Previous study finds that betaine can decrease fat deposition and improve the lean meat percentage of animals [34]. Present results indicated that dietary with betaine supplementation decreased fat percentage and back fat thickness. The reason for the decrease of fat deposition might be related to genes expression. The present study indicated that dietary with betaine supplementation regulated the genes mRNA expression in subcutaneous 
back fat (downregulated the ACC and FAS mRNA expression and upregulated the ATGL and Sirt1 mRNA expression), and the results were in line with the findings previously described in literature [35]. Therefore, the mechanism might be related to the function of modification of DNA methylation with betaine. Besides, there are reports found that choline diet could mitigate excessive fat deposition, while betaine could change into choline in body [36,37]. Kim et al. [38] reported that the ACC mRNA expression in viral-induced mice downregulated after diet with betaine was supplemented. Another study indicated gene methylation levels of the ACC in diet with betaine supplementation group mice was higher than control group, which verified betaine may regulate the expression of ACC by supplying methyl [39]. Besides, diet with betaine supplementation can also regulate the expression of ACC by regulating other genes [30,31]. FAS, the finally rate-limiting enzyme for fatty acid de novo synthesis, mainly exist in the liver and fat tissues, which can catalyze the synthesis of acetyl-CoA and malonyl-CoA into long-chain fatty acids [40]. High-fat diet promotes high expression of FAS [41]. Current results had verified betaine dietary downregulated the FAS and ACC mRNA expression in fat by Yang et al. [42] and Dong et al. [43]. ATGL can regulate the deposition of fat by regulating the process of triglyceride decomposition [44]. It is reported that systemic and adipocyte-specific ATGL knockout mice exhibit moderate obesity [45]. In addition, ATGL can promote the expression of Sirt1 [46]. Sathyanarayan et al. [47] found the high expression of ATGL on mice showed excessive fat deposition, and the situation was found to alleviate after the knockdown of Sirt1, which proved that the function of ATGL on fat metabolism appears to be mediated by Sirt1. Zhao et al. [48] found that betaine diet could upregulate the ATGL mRNA expression in fat by modification of DNA methylation. In summary, the present study suggested that betaine could mitigate excessive fat deposition by downregulating the expression of ACC and FAS and upregulating the expression of ATGL and Sirt1.

\section{Conclusions}

In conclusion, diet supplemented with betaine could decrease fat deposition via regulating the expression of genes related to lipid metabolism. In addition, diet supplemented with betaine could improve meat quality via increasing water-holding capacity and tenderness in muscles of finishing Ningxiang pigs.

Author Contributions: Investigation, Y.W., J.C. and Y.J.; writing-original draft preparation, Y.W.; writing-review and editing, J.C. and X.L.; project administration, Y.Z.; funding acquisition, Y.Z. All authors have read and agreed to the published version of the manuscript.

Funding: This study was supported by Scientific Research Fund of Hunan Provincial Education Department (18A087) and National Top Disciplines Development Project for Innovation Teams (kxk201801004).

Institutional Review Board Statement: The experimental procedures were approved by Biomedical Research Ethics Committee of Hunan Agricultural University (Changsha, China) (2021, No. 91).

Informed Consent Statement: Not applicable.

Data Availability Statement: The data presented in this study are available from the corresponding author upon request.

Acknowledgments: The authors thank the students who aided in the collection of samples for this study. The authors thank the Hunan Agricultural University for support.

Conflicts of Interest: No conflict of interest exists in this manuscript.

\section{References}

1. He, C.; Zhang, Q.; Sun, H.; Cai, R.; Pang, W. Role of miRNA and lncRNA in animal fat deposition-A review. Sheng Wu Gong Cheng Xue Bao 2020, 36, 1504-1514. [PubMed]

2. Suzuki, S.; Kobayashi, M.; Murai, A.; Tsudzuki, M.; Ishikawa, A. Characterization of Growth, Fat Deposition, and Lipid Metabolism-Related Gene Expression in Lean and Obese Meat-Type Chickens. J. Poult. Sci. 2019, 56, 101-111. [CrossRef] [PubMed] 
3. Feng, Z.; Guo, J.; Kong, X.; Wang, W.; Yin, Y. Molecular cloning and expression profiling of G protein coupled receptor 120 in Landrace pig and different Chinese indigenous pig breeds. J. Food Agric. Environ. 2012, 10, 809-814.

4. Lei, L.; Wang, Z.; Li, J.; Yang, H.; Yin, Y.; Tan, B.; Chen, J. Comparative Microbial Profiles of Colonic Digesta between Ningxiang Pig and Large White Pig. Animals 2021, 11, 1862. [CrossRef]

5. He, Q.; Ren, P.; Kong, X.; Wu, Y.; Wu, G.; Li, P.; Hao, F.; Tang, H.; Blachier, F.; Yin, Y. Comparison of serum metabolite compositions between obese and lean growing pigs using an NMR-based metabonomic approach. J. Nutr. Biochem. 2012, 23, 133-139. [CrossRef]

6. Fernández-Fígares, I.; Lachica, M.; Martínez-Pérez, M.; Ramsay, T. Conjugated linoleic acid and betaine affect lipolysis in pig adipose tissue explants. Animal 2019, 13, 2840-2846. [CrossRef]

7. Fernández-Fígares, I.; Conde-Aguilera, J.; Nieto, R.; Lachica, M.; Aguilera, J. Synergistic effects of betaine and conjugated linoleic acid on the growth and carcass composition of growing Iberian pigs. J. Anim. Sci. 2008, 86, 102-111. [CrossRef]

8. Xiong, B.; Pang, Z.; Luo, Q. Tables of feed composition and nutritive values in China (30th edition in 2019). China Feed 2019, 22, 111-116.

9. Honikel, K.O. Reference methods for the assessment of physical characteristics of Meat. Meat Sci. 1998, 49, 447-457. [CrossRef]

10. Chen, J.; Chen, F.; Lin, X.; Wang, Y.; He, J.; Zhao, Y. Effect of Excessive or Restrictive Energy on Growth Performance, Meat Quality, and Intramuscular Fat Deposition in Finishing Ningxiang Pigs. Animals 2021, 11, 27. [CrossRef]

11. Horwitz, W. Official Methods of Analysis of AOAC International, 17th ed.; Association of Official Analytical Chemists: Gaithersburg, MD, USA, 2000.

12. Yin, J.; Li, Y.; Zhu, X.; Han, H.; Ren, W.; Chen, S.; Bin, P.; Liu, G.; Huang, X.; Fang, R.; et al. Effects of Long-Term Protein Restriction on Meat Quality, Muscle Amino Acids, and Amino Acid Transporters in Pigs. J. Agric. Food Chem. 2017, 65, 9297-9304. [CrossRef]

13. Zhong, Y.; Yan, Z.; Song, B.; Zheng, C.; Duan, Y.; Kong, X.; Deng, J.; Li, F. Dietary supplementation with betaine or glycine improves the carcass trait, meat quality and lipid metabolism of finishing mini-pigs. Anim. Nutr. 2021, 7, 376-383. [CrossRef] [PubMed]

14. Albuquerque, A.; Neves, J.A.; Redondeiro, M.; Laranjo, M.; Félix, M.R.; Freitas, A.; Tirapicos, J.L.; Martins, J.M. Long term betaine supplementation regulates genes involved in lipid and cholesterol metabolism of two muscles from an obese pig breed. Meat Sci. 2017, 124, 25-33. [CrossRef] [PubMed]

15. Sales, J. A meta-analysis of the effects of dietary betaine supplementation on finishing performance and carcass characteristics of pigs. Anim. Feed. Sci. Technol. 2011, 165, 68-78. [CrossRef]

16. Tomasevic, I.; Djekic, I.; Furnol, M.; Terjung, N.; Lorenzo, J.M. Recent advances in meat color research. Curr. Opin. Food Sci. 2021, 41,81-87. [CrossRef]

17. Wood, J.D.; Enser, M.; Fisher, A.V.; Nute, G.R.; Sheard, P.R.; Richardson, R.I.; Hughes, S.I.; Whittington, F.M. Fat deposition, fatty acid composition and meat quality: A review. Meat Sci. 2008, 78, 343-358. [CrossRef]

18. Teye, G.A.; Sheard, P.R.; Whittington, F.M.; Nute, G.R.; Stewart, A.; Wood, J.D. Influence of dietary oils and protein level on pork quality. 1. Effects on muscle fatty acid composition, carcass, meat and eating quality. Meat Sci. 2006, 73, 157-165. [CrossRef]

19. Wen, Y.; Liu, H.; Liu, K.; Cao, H.; Mao, H.; Dong, X.; Yin, Z. Analysis of the physical meat quality in partridge (Alectoris chukar) and its relationship with intramuscular fat. Poult Sci. 2020, 99, 1225-1231. [CrossRef] [PubMed]

20. Yu, Q.P.; Feng, D.Y.; Xiao, J.; Wu, F.; He, X.J.; Xia, M.H.; Dong, T.; Liu, Y.H.; Tan, H.Z.; Zou, S.G.; et al. Studies on meat color, myoglobin content, enzyme activities, and genes associated with oxidative potential of pigs slaughtered at different growth stages. Asian-Australas. J. Anim. Sci. 2017, 30, 1739-1750. [CrossRef]

21. Wang, L.; Shi, B.; Shan, A.; Zhang, Y. Effects of guanidinoacetic acid on growth performance, meat quality and antioxidation in growing-finishing pigs. J. Anim. Vet. Adv. 2012, 11, 631-636. [CrossRef]

22. Liu, Y.; Li, J.L.; Li, Y.J.; Gao, T.; Zhang, L.; Gao, F.; Zhou, G.H. Effects of dietary supplementation of guanidinoacetic acid and combination of guanidinoacetic acid and betaine on postmortem glycolysis and meat quality of finishing pigs. Anim. Feed. Sci. Technol. 2015, 205, 82-89. [CrossRef]

23. Bertol, T.M.; Ellis, M.; Ritter, M.J.; McKeith, F.K. Effect of feed withdrawal and handling intensity on longissimus muscle glycolytic potential and blood measurements in slaughter weight pigs. J. Anim. Sci. 2005, 83, 1536-1542. [CrossRef]

24. Joo, S.T.; Kauffman, R.G.; Kim, B.C.; Park, G.B. The relationship of sarcoplasmic and myofibrillar protein solubility to colour and water-holding capacity in porcine longissimus muscle. Meat Sci. 1999, 52, 291-297. [CrossRef]

25. Gao, Y.; Zhang, Y.H.; Zhang, S.; Li, F.; Wang, S.; Dai, L.; Jiang, H.; Xiao, S.; Liu, D.; Sun, B.; et al. Association of A-FABP gene polymorphism in intron 1 with meat quality traits in Junmu No. 1 white swine. Gene 2011, 487, 170-173. [CrossRef] [PubMed]

26. Haunerland, N.H.; Spener, F. Fatty acid-binding proteins-insights from genetic manipulations. Prog. Lipid Res. 2004, 43, 328-349. [CrossRef] [PubMed]

27. Prinsen, C.F.; Weghuis, D.O.; Kessel, A.G.; Veerkamp, J.H. Identification of a human heart FABP pseudogene located on chromosome 13. Gene 1997, 193, 245-251. [CrossRef]

28. Dong, L.; Jin, Y.; Cui, H.; Yu, L.; Luo, Y.; Wang, S.; Wang, H. Effects of diet supplementation with rumen-protected betaine on carcass characteristics and fat deposition in growing lambs. Meat Sci. 2020, 166, 108154. [CrossRef]

29. Ayonrinde, O.T. Historical narrative from fatty liver in the nineteenth century to contemporary NAFLD—Reconciling the present with the past. JHEP Rep. 2021, 3, 100261. [CrossRef]

30. Ahn, C.W.; Choi, Y.J.; Hong, S.H.; Jun, D.S.; Na, J.D.; Choi, Y.J.; Kim, Y.C. Involvement of multiple pathways in the protection of liver against high-fat diet-induced steatosis by betaine. J. Funct. Foods 2015, 17, 66-72. [CrossRef] 
31. Ahn, C.W.; Jun, D.S.; Na, J.D.; Choi, Y.J.; Kim, Y.C. Alleviation of hepatic fat accumulation by betaine involves reduction of homocysteine via up-regulation of betaine-homocysteine methyltransferase (BHMT). Biochem. Biophys. Res. Commun. 2016, 477, 440-447. [CrossRef]

32. Liu, C.; Grant, A.; Kim, K.H.; Mills, S.E. Porcine somatotropin decreases acetyl-CoA carboxylase gene expression in porcine adipose tissue. Domest. Anim. Endocrinol. 1994, 11, 125-132. [CrossRef]

33. Smith, S.; Witkowski, A.; Joshi, A.K. Structural and functional organization of the animal fatty acid synthase. Prog. Lipid Res. 2003, 42, 289-317. [CrossRef]

34. Rojas-Cano, M.L.; Lara, L.; Lachica, M.; Aguilera, J.F.; Fernández-Fígares, I. Influence of betaine and conjugated linoleic acid on development of carcass cuts of Iberian pigs growing from 20 to $50 \mathrm{~kg}$ body weight. Meat Sci. 2011, 88, 525-530. [CrossRef] [PubMed]

35. Yang, Z.; Asare, E.; Yang, Y.; Yang, J.J.; Yang, H.M.; Wang, Z.Y. Dietary supplementation of betaine promotes lipolysis by regulating fatty acid metabolism in geese. Poult. Sci. 2021, 100, 101460. [CrossRef]

36. Brown, A.L.; Conrad, K.; Allende, D.S.; Gromovsky, A.D.; Zhang, R.; Neumann, C.K.; Owens, A.P.; Tranter, M.; Helsley, R.N. Dietary Choline Supplementation Attenuates High-Fat-Diet-Induced Hepatocellular Carcinoma in Mice. J. Nutr. 2020, 150, 775-783. [CrossRef] [PubMed]

37. Aldana-Hernández, P.; Leonard, K.A.; Zhao, Y.Y.; Curtis, J.M.; Field, C.J.; Jacobs, R.L. Dietary Choline or Trimethylamine N-oxide Supplementation Does Not Influence Atherosclerosis Development in $\mathrm{Ldll}^{-/-}$and Apoe ${ }^{-/-}$Male Mice. J. Nutr. 2020, 150, 249-255. [CrossRef]

38. Kim, D.H.; Lee, B.; Kim, M.J.; Park, M.H.; An, H.J.; Lee, E.K.; Chung, K.W.; Park, J.W.; Yu, B.P.; Choi, J.S.; et al. Molecular mechanism of betaine on hepatic lipid metabolism: Inhibition of FoxO1 binding to PPARg. J. Agric. Food Chem. 2016, 64, 6819-6825. [CrossRef]

39. Zhao, N.; Yang, S.; Jia, Y.; Sun, B.; He, B.; Zhao, R. Maternal betaine supplementation attenuates glucocorticoid-induced hepatic lipid accumulation through epigenetic modification in adult offspring rats. J. Nutr. Biochem. 2017, 54, 105-112. [CrossRef] [PubMed]

40. Postic, C.; Girard, J. Contribution of de novo fatty acid synthesis to hepatic steatosis and insulin resistance: Lessons from genetically engineered mice. J. Clin. Investig. 2008, 118, 829-838. [CrossRef]

41. Abd-Rabo, F.H.R.; Elshaghabee, F.M.F.; Sakr, S.S.; El-Arabi, N.I.; El-Maaty, S.A. Different dietary fats impact on biochemical and histological parameters and gene expression of lipogenesis-related genes in rats. Food Biosci. 2020, 34, 100540. [CrossRef]

42. Yang, W.; Huang, L.; Gao, J.; Wen, S.; Tai, Y.; Chen, M.; Huang, Z.; Liu, R.; Tang, C.; Li, J. Betaine attenuates chronic alcohol-induced fatty liver by broadly regulating hepatic lipid metabolism. Mol. Med. Rep. 2017, 16, 5225-5234. [CrossRef] [PubMed]

43. Dong, X.; Xue, W.; Hua, J.; Hang, Y.; Sun, L.; Miao, S.; Wei, W.; Wu, X.; Du, X. Effects of dietary betaine in allogynogenetic gibel carp (Carassius auratus gibelio): Enhanced growth, reduced lipid deposition and depressed lipogenic gene expression. Aquac. Res. 2018, 49, 1967-1972. [CrossRef]

44. Schreiber, R.; Xie, H.; Schweiger, M. Of mice and men: The physiological role of adipose triglyceride lipase (ATGL). Biochim. Biophys. Acta (BBA) Mol. Cell Biol. Lipids 2019, 1864, 880-899. [CrossRef] [PubMed]

45. Haemmerle, G.; Lass, A.; Zimmermann, R.; Gorkiewicz, G.; Meyer, C.; Rozman, J.; Heldmaier, G.; Maier, R.; Theussl, C.; Eder, S.; et al. Defective lipolysis and altered energy metabolism in mice lacking adipose triglyceride lipase. Science 2006, 312, 734-737. [CrossRef]

46. Khan, S.A.; Sathyanarayan, A.; Mashek, M.T.; Ong, K.T.; Wollaston-Hayden, E.E.; Mashek, D.G. ATGL-catalyzed lipolysis regulates SIRT1 to control PGC-1 $\alpha /$ PPAR- $\alpha$ signaling. Diabetes 2015, 64, 418-426. [CrossRef]

47. Sathyanarayan, A.; Mashek, M.T.; Mashek, D.G. ATGL Promotes Autophagy/Lipophagy via SIRT1 to Control Hepatic Lipid Droplet Catabolism. Cell Rep. 2017, 19, 1-9. [CrossRef] [PubMed]

48. Zhao, N.; Yang, S.; Sun, B.; Feng, Y.; Zhao, R. Maternal betaine protects rat offspring from glucocorticoid-induced activation of lipolytic genes in adipose tissue through modification of DNA methylation. Eur. J. Nutr. 2020, 59, 1707-1716. [CrossRef] 